\title{
Selective catalytic oxidation of ammonia from MAP decomposition
}

\author{
Shilong He, Changbin Zhang, Min Yang, Yu Zhang, Wenqing Xu, Nan Cao, Hong He* \\ Research Center for Eco-Environmental Sciences, Chinese Academy of Sciences, \\ 18 Shuangqing Road, P.O. Box 2871, Beijing 100085, China
}

\begin{abstract}
The $\mathrm{Cu} / \mathrm{TiO}_{2}$ catalysts with different $\mathrm{Cu}$ loadings were prepared, and their performance in the selective catalytic oxidation of ammonia (SCO of $\mathrm{NH}_{3}$ ) was compared with $10 \% \mathrm{Cu} / \mathrm{Al}_{2} \mathrm{O}_{3}$. The $10 \% \mathrm{Cu} / \mathrm{TiO}_{2}$ has the best performance among its series for $\mathrm{NH}_{3}$ conversion and $\mathrm{N}_{2}$ selectivity. At $250{ }^{\circ} \mathrm{C}$, the $100 \%$ conversion of ammonia was achieved and the selectivity to $\mathrm{N}_{2}$ came to $95 \%$. The $10 \% \mathrm{Cu} / \mathrm{TiO}_{2}$ catalyst has a much higher activity for the SCO of ammonia and a slightly lower $\mathrm{N}_{2}$ selectivity than $10 \% \mathrm{Cu} / \mathrm{Al}_{2} \mathrm{O}_{3}$ because of the higher oxygen mobility and lower oxygen bonding strength, which demonstrated that $\mathrm{TiO}_{2}$ is a more suitable support than $\mathrm{Al}_{2} \mathrm{O}_{3}$ for copper-based catalyst in the $\mathrm{SCO}$ of $\mathrm{NH}_{3}$. The mechanisms involved in the $\mathrm{SCO}$ of $\mathrm{NH}_{3}$ reaction on the $10 \% \mathrm{Cu} / \mathrm{TiO}_{2}$ catalyst have also been investigated using TPD, TPR as well as in situ DRIFTS methods. (C) 2007 Elsevier B.V. All rights reserved.
\end{abstract}

Keywords: Selective catalytic oxidation of ammonia; Copper; Titania; Alumina; In situ DRIFTS

\section{Introduction}

Formation of magnesium ammonium phosphate (MAP) has been considered to be an effective method for the removal of ammonium from landfill leachate because of its high reaction rate and low residual ammonium concentration [1-3]. However, the high operating cost, due to the continual addition of fresh phosphate and magnesium, is the main obstacle to widespread application of the MAP process. This problem can be effectively solved by repeated use of the MAP decomposition residues formed at the conditions of $\mathrm{NH}_{4}^{+}: \mathrm{OH}^{-}$molar ratio, 1:1; temperature, $90^{\circ} \mathrm{C}$; heating time, $2 \mathrm{~h}$, and the chemical costs can be saved for about $50 \%$ by reuse of MAP for 3 cycles [4]. The high ammonia emission in the process of MAP decomposition, however, should be controlled properly to prevent serious air pollution.

Among the methods to abate ammonia emission, low temperature selective catalytic oxidation (SCO) of ammonia to nitrogen is potentially seen as an ideal technology $[5,6]$. Previous studies show that noble metals such as $\mathrm{Pt}$ is active for this reaction at low temperature but deactivate rapidly with time [7]. Silver based catalysts have a high activity for ammonia conversion, but the $\mathrm{N}_{2}$ selectivity is relatively low at the temperature range investigated [8]. $\mathrm{Al}_{2} \mathrm{O}_{3}$-supported metal oxide catalysts such as $\mathrm{Cr}_{3} \mathrm{O}_{4}$,

\footnotetext{
* Corresponding author. Tel.: +86 1062849123 ; fax: +86 1062849123 . E-mail address: honghe@rcees.ac.cn (H. He).
}

$\mathrm{Fe}_{2} \mathrm{O}_{3}, \mathrm{CuO}$ and $\mathrm{MoO}_{3}$ have been widely studied, but ammonia conversion levels are not high enough at low temperatures to be of practical use [9-12].

In our previous study, we found that alumina supported copper-silver catalyst had a good conversion and selectivity to $\mathrm{N}_{2}$, and the complete ammonia conversion could be achieved at $320^{\circ} \mathrm{C}$ [13]. However, the conversion temperature is still too high for the oxidation of ammonia produced during MAP decomposition. Sazonova et al. [14] had reported that the $\mathrm{Cu} / \mathrm{TiO}_{2}$ catalyst possessed a good activity for the SCO of ammonia to $\mathrm{N}_{2}$ at the temperature around $300^{\circ} \mathrm{C}$. However, the reaction mechanism, limitative conditions and characterization of this catalyst were not detailed in this report.

In this study, we prepared $\mathrm{Cu} / \mathrm{TiO}_{2}$ catalysts with different $\mathrm{Cu}$ loadings, and evaluated the activity of $\mathrm{Cu} / \mathrm{TiO}_{2}$ catalysts for the SCO of ammonia to $\mathrm{N}_{2}$ in detail. X-ray diffraction analysis (XRD), temperature programmed desorption (TPD) and reduction (TPR) as well as in situ diffuse reflectance infrared Fourier transform spectroscopy (DRIFTS) were used for a better understanding of the $\mathrm{SCO}$ of ammonia on $\mathrm{Cu} / \mathrm{TiO}_{2}$ catalyst.

\section{Experimental}

\subsection{Catalyst preparation}

The $\mathrm{TiO}_{2}$ and $\mathrm{Al}_{2} \mathrm{O}_{3}$ supported copper catalysts were prepared by an impregnation method with an anatase type $\mathrm{TiO}_{2}$ (Shanghai, China) and an aqueous solution of $\mathrm{Cu}\left(\mathrm{NO}_{3}\right)_{2}$. After 
impregnation, the excessive water was removed in a rotary evaporator at $80^{\circ} \mathrm{C}$. The samples were dried at $110^{\circ} \mathrm{C}$ for $12 \mathrm{~h}$ and then calcined at $450{ }^{\circ} \mathrm{C}$ for $3 \mathrm{~h}$.

\subsection{Activity test of catalyst}

The activity tests for the $\mathrm{SCO}$ of $\mathrm{NH}_{3}$ over catalysts were performed with a fixed-bed quartz flow reactor by passing a gas mixture of $\mathrm{NH}_{3} / \mathrm{O}_{2} / \mathrm{He}=400 \mathrm{ppm} / 10 \mathrm{vol} \% / \mathrm{balance}$ at a total flow rate of $500 \mathrm{~cm}^{3} \mathrm{~min}^{-1}$ (gas hourly space velocities (GHSV): 50,000 $\mathrm{h}^{-1}$ ). Ammonia, oxygen and helium flow rates were controlled by mass flow controllers. Water was supplied with a micro-pump into the gas steam and vaporized by a coiled heater at the inlet of the reactor. The inlet and outlet gas compositions were analyzed by an on-line NEXUS 670-FTIR fitted with a gas cell of volume $2 \mathrm{dm}^{3}$.

\subsection{Characterization of catalyst}

BET surface areas were obtained from $\mathrm{N}_{2}$ adsorption isotherms measured at $77 \mathrm{~K}$ using an ASAP 2000 instrument (Micromeritics Co. USA). Powder X-ray diffraction (XRD) measurements of catalysts were carried out on a Rigaku D/max$\mathrm{RB}$ X-ray diffractometer (Japan) with a $\mathrm{Cu} \mathrm{K} \alpha$ radiation and operated at $40 \mathrm{kV}$ and $40 \mathrm{~mA}$. The patterns were taken in the $2 \theta$ range of $10-70^{\circ}$ at a scan speed of $6^{\circ} \mathrm{min}^{-1}$.

$\mathrm{NH}_{3}$-TPD or TPR experiments were performed using a fixedbed flow reactor system equipped with a computer-interfaced quadruple mass spectrometer (Hiden HPR 20). After adsorption of $\mathrm{NH}_{3}$ at room temperature the TPD or TPR data were recorded by mass spectrometer while the temperature was increased from 50 to $500^{\circ} \mathrm{C}$ at a heating rate of $20^{\circ} \mathrm{C} / \mathrm{min}$.

\subsection{In situ DRIFTS}

In situ DRIFT spectra were recorded in a NEXUS 670FTIR equipped with a smart collector and a liquid $\mathrm{N}_{2}$ cooled MCT detector. The sample (about $30 \mathrm{mg}$ ) for study was finely grounded and placed in a ceramic crucible. A flow of feed gas mixture was controlled by mass flow meters. All spectra were recorded with a resolution of $4 \mathrm{~cm}^{-1}$ and accumulating 100 scans. The background spectrum was subtracted from each spectrum, respectively.

\section{Results and discussion}

\subsection{Catalytic test}

\subsubsection{Ammonia oxidation on copper-based catalysts}

The $\mathrm{NH}_{3}$ conversion performance of $\mathrm{Cu} / \mathrm{TiO}_{2}$ catalysts with different $\mathrm{Cu}$ loadings was compared with that of $10 \% \mathrm{Cu} / \mathrm{Al}_{2} \mathrm{O}_{3}$ (weight percent, hereinafter) at various temperatures, and the results are shown in Figs. 1 and 2. The $\mathrm{NH}_{3}$ conversion increased significantly with the increase of copper loading from 1 to $10 \%$, and then remained almost unchanged with the further increase of copper loading from 10 to $20 \%$. It is clear that activity of $10 \% \mathrm{Cu} / \mathrm{TiO}_{2}$ for the $\mathrm{NH}_{3}$ conversion was far higher than that

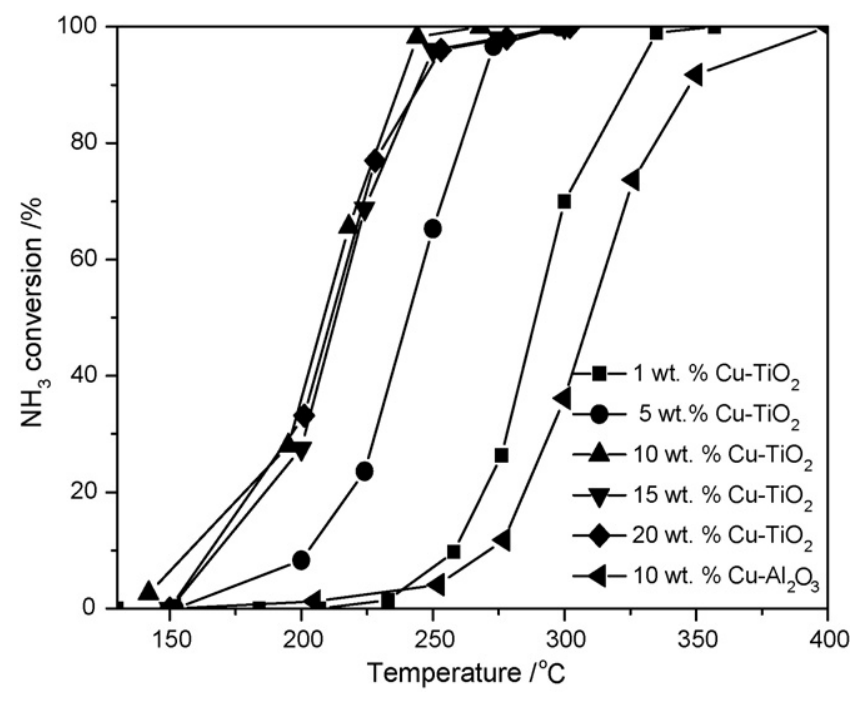

Fig. 1. $\mathrm{NH}_{3}$ conversion during the $\mathrm{SCO}$ of $\mathrm{NH}_{3}$ over $\mathrm{Cu} / \mathrm{TiO}_{2}$ with different $\mathrm{Cu}$ loadings and $10 \% \mathrm{Cu} / \mathrm{Al}_{2} \mathrm{O}_{3}$ catalysts. Reaction conditions: $0.2 \mathrm{~g}$ catalyst, $\left[\mathrm{NH}_{3}\right]=400 \mathrm{ppm},\left[\mathrm{O}_{2}\right]=10 \%, \mathrm{He}=$ balance, total flow rate $=500 \mathrm{ml} \mathrm{min}^{-1}$ and $\mathrm{GHSV}=50,000 \mathrm{~h}^{-1}$.

of $10 \% \mathrm{Cu} / \mathrm{Al}_{2} \mathrm{O}_{3}(100 \%$ ammonia conversion was achieved at about $350^{\circ} \mathrm{C}$ ), which was developed in the previous study [15]. The selectivity of $\mathrm{NH}_{3}$ to $\mathrm{N}_{2}$, on the other hand, decreased with the increase of copper content. Chmielarz et al. [16] found that the increase of copper loading favors the formation of surface metal oxide clusters and decreases the oxygen bonding strength, leading to the decrease of $\mathrm{N}_{2}$ selectivity of $\mathrm{Cu} / \mathrm{Mg} / \mathrm{Al}$ catalysts. Therefore, considering $\mathrm{NH}_{3}$ conversion and $\mathrm{N}_{2}$ selectivity, the $10 \% \mathrm{Cu} / \mathrm{TiO}_{2}$ is the best one among its series catalysts, over which complete conversion of $\mathrm{NH}_{3}$ and an $\mathrm{N}_{2}$ selectivity of $95 \%$ were obtained at $250{ }^{\circ} \mathrm{C}$. In comparison with the $10 \% \mathrm{Cu} / \mathrm{Al}_{2} \mathrm{O}_{3}$ catalyst, the $10 \% \mathrm{Cu} / \mathrm{TiO}_{2}$ catalyst demonstrated a similar $\mathrm{N}_{2}$ selectivity but a much high catalytic activity for ammonia oxidation. This indicates that $\mathrm{TiO}_{2}$ is a more suitable support than $\mathrm{Al}_{2} \mathrm{O}_{3}$ for copper-based catalyst in the $\mathrm{SCO}$ of $\mathrm{NH}_{3}$.

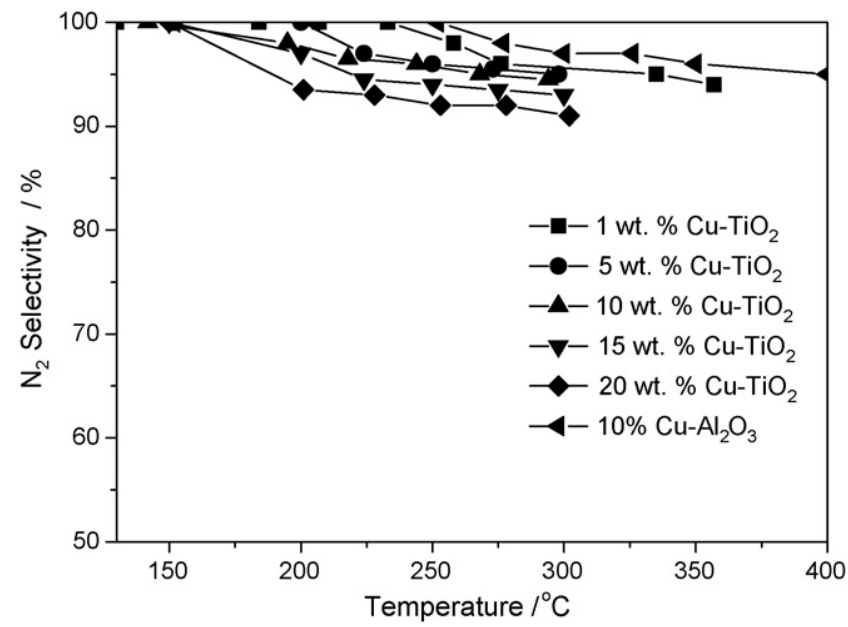

Fig. 2. $\mathrm{N}_{2}$ selectivity during the $\mathrm{SCO}$ of $\mathrm{NH}_{3}$ over $\mathrm{Cu} / \mathrm{TiO}_{2}$ with different $\mathrm{Cu}$ loadings and $10 \% \mathrm{Cu} / \mathrm{Al}_{2} \mathrm{O}_{3}$ catalysts. Reaction conditions: $0.2 \mathrm{~g}$ catalyst, $\left[\mathrm{NH}_{3}\right]=400 \mathrm{ppm},\left[\mathrm{O}_{2}\right]=10 \%, \mathrm{He}=$ balance, total flow rate $=500 \mathrm{ml} \mathrm{min}^{-1}$ and $\mathrm{GHSV}=50,000 \mathrm{~h}^{-1}$. 


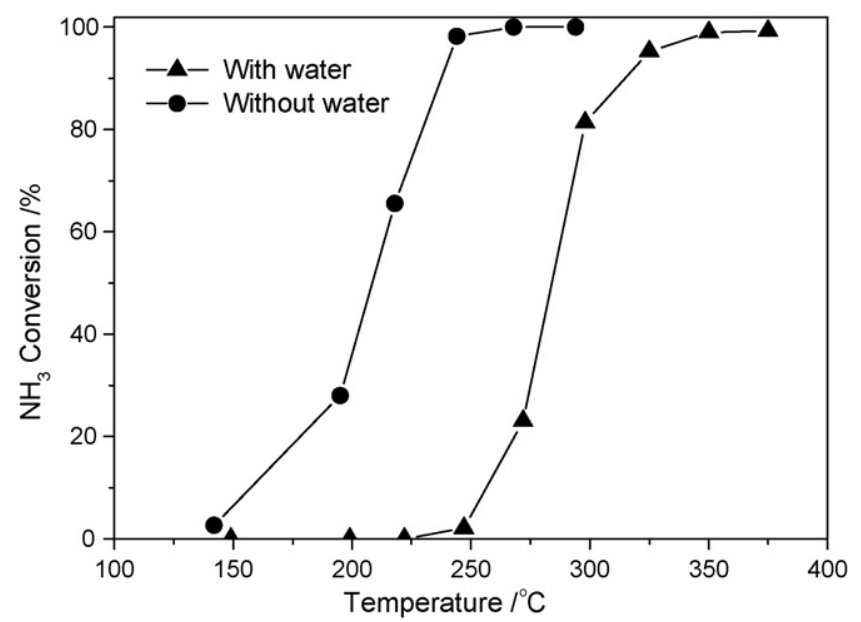

Fig. 3. Effect of $\mathrm{H}_{2} \mathrm{O}$ on $\mathrm{NH}_{3}$ conversion for $10 \% \mathrm{Cu} / \mathrm{TiO}_{2}$ catalyst. Reaction conditions: $0.2 \mathrm{~g}$ catalyst, $\left[\mathrm{NH}_{3}\right]=400 \mathrm{ppm},\left[\mathrm{O}_{2}\right]=10 \%, 3 \%$ water vapor, $\mathrm{He}=$ balance, total flow rate $=500 \mathrm{ml} \mathrm{min}^{-1}$ and GHSV $=50,000 \mathrm{~h}^{-1}$.

\subsubsection{Effect of water on catalytic activity}

It is known that waste streams sometimes contain water vapour, so the effect of water on the catalytic performance of the $10 \% \mathrm{Cu} / \mathrm{TiO}_{2}$ was investigated. As shown in Fig. 3, the temperature for complete $\mathrm{NH}_{3}$ conversion increased for about $100^{\circ} \mathrm{C}$ when $3 \% \mathrm{H}_{2} \mathrm{O}$ existed in the waste stream, indicating the existence of adverse effects by water composition. It is likely that water competes with ammonia for the absorption sites [17]. As shown in Fig. 4, the $\mathrm{N}_{2}$ selectivity was hardly influenced by the existence of water in the waste stream. Therefore, it is important that the content of water should be checked in utilizing the catalyst for the removal of $\mathrm{NH}_{3}$.

\section{2. $X R D$ and BET results}

Fig. 5 shows the XRD patterns of $\mathrm{Cu} / \mathrm{TiO}_{2}$ catalysts with different $\mathrm{Cu}$ loadings. All the catalysts exhibited the typical patterns of anatase $\mathrm{TiO}_{2}$, and the XRD intensity of $\mathrm{TiO}_{2}$ did not change with the changes of $\mathrm{Cu}$ loading. Perceptible XRD pat-

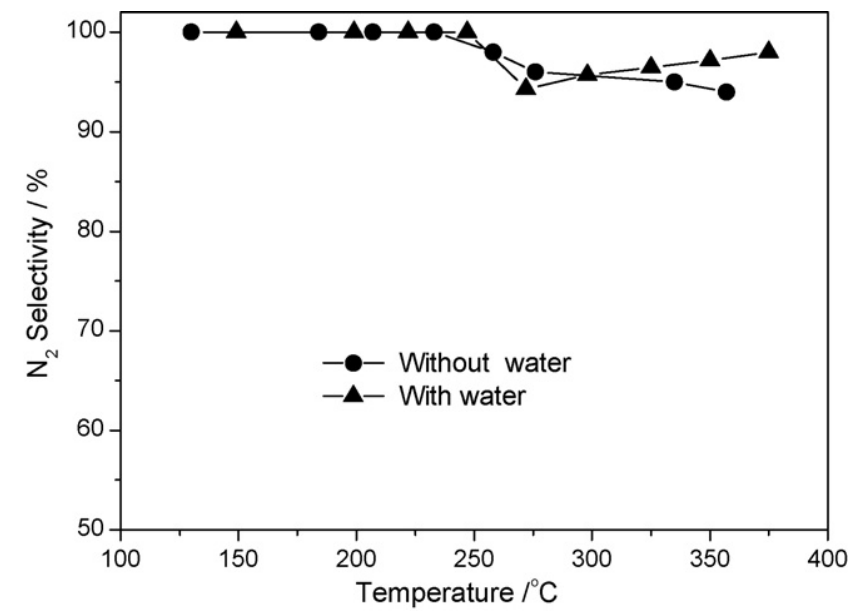

Fig. 4. Effect of $\mathrm{H}_{2} \mathrm{O}$ on $\mathrm{N}_{2}$ selectivity for $10 \% \mathrm{Cu} / \mathrm{TiO}_{2}$ catalyst. Reaction conditions: $0.2 \mathrm{~g}$ catalyst, $\left[\mathrm{NH}_{3}\right]=400 \mathrm{ppm},\left[\mathrm{O}_{2}\right]=10 \%, 3 \%$ water vapor, $\mathrm{He}=$ balance, total flow rate $=500 \mathrm{ml} \mathrm{min}^{-1}$ and $\mathrm{GHSV}=50,000 \mathrm{~h}^{-1}$.

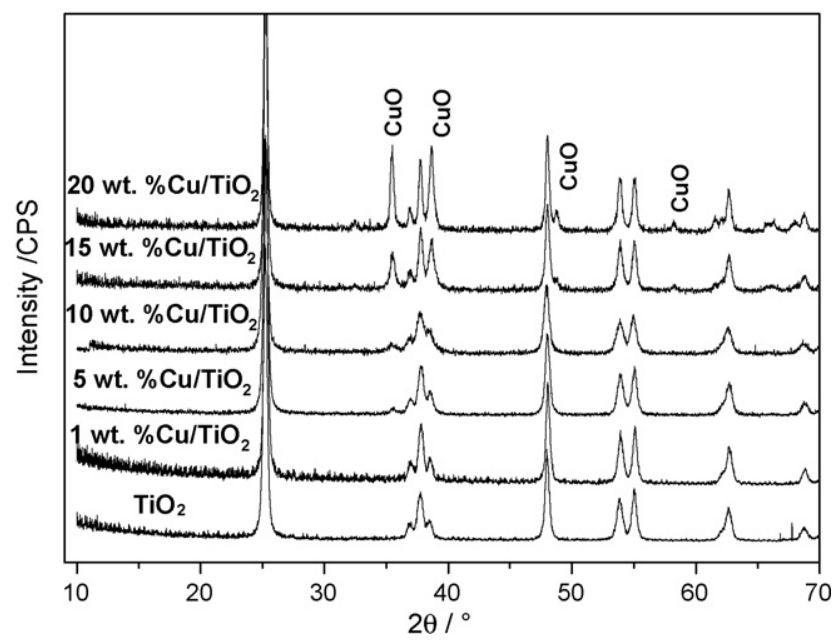

Fig. 5. XRD patterns of $\mathrm{Cu} / \mathrm{TiO}_{2}$ catalysts with different $\mathrm{Cu}$ loadings.

tern (35.5, 38.6, 48.9 and 58.3) attributable to crystallized $\mathrm{CuO}$ was observed with the loading of $\mathrm{Cu}$ increased. It means that the particles of $\mathrm{CuO}$ well dispersed on the surface of $\mathrm{TiO}_{2}$ at low copper loadings, and the increase of copper loading caused the aggregation of $\mathrm{CuO}$ on the $\mathrm{TiO}_{2}$ surface. As shown in Fig. 6, the XRD spectrum of $10 \% \mathrm{Cu} / \mathrm{TiO}_{2}$ only exhibited very weak diffractive pattern attributable to crystallized $\mathrm{CuO}$, and the XRD spectrum of $10 \% \mathrm{Cu} / \mathrm{Al}_{2} \mathrm{O}_{3}$ did not show any $\mathrm{CuO}$ pattern. This indicates that particle size of $\mathrm{CuO}$ deposited on $\mathrm{TiO}_{2}$ is larger than that on $\mathrm{Al}_{2} \mathrm{O}_{3}$, and the $\mathrm{CuO}$ phase is much higher dispersed on $\mathrm{Al}_{2} \mathrm{O}_{3}$ than $\mathrm{TiO}_{2}$. Combining the XRD results with the results in Figs. 1 and 2, it is indicated that the $\mathrm{N}_{2}$ selectivity related with $\mathrm{CuO}$ particle size [16].

BET surface areas of $\mathrm{Cu} / \mathrm{TiO}_{2}$ catalysts with different $\mathrm{Cu}$ loadings are shown in Table 1 together with that of $10 \%$ $\mathrm{Cu} / \mathrm{Al}_{2} \mathrm{O}_{3}$. Table 1 shows that the loading of copper did not affect the structure of $\mathrm{TiO}_{2}$ except for the case of $20 \% \mathrm{Cu} / \mathrm{TiO}_{2}$. Compared with $10 \% \mathrm{Cu} / \mathrm{TiO}_{2}, 10 \% \mathrm{Cu} / \mathrm{Al}_{2} \mathrm{O}_{3}$ has a much higher surface area, which may be the reason that the dispersion of $\mathrm{CuO}$ on $10 \% \mathrm{Cu} / \mathrm{Al}_{2} \mathrm{O}_{3}$ was better than that of $10 \% \mathrm{Cu} / \mathrm{TiO}_{2}$. These results also indicate that BET surface area was not the

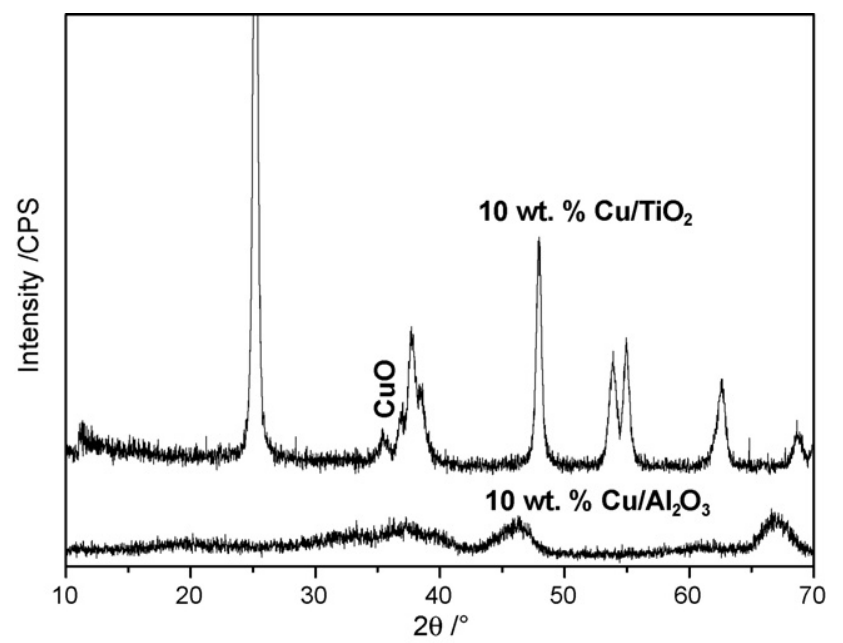

Fig. 6. XRD patterns of $10 \% \mathrm{Cu} / \mathrm{TiO}_{2}$ and $10 \% \mathrm{Cu} / \mathrm{Al}_{2} \mathrm{O}_{3}$ catalysts. 
Table 1

BET surface areas of $\mathrm{Cu} / \mathrm{TiO}_{2}$ catalysts with different $\mathrm{Cu}$ loadings and $10 \%$ $\mathrm{Cu} / \mathrm{Al}_{2} \mathrm{O}_{3}$

\begin{tabular}{ll}
\hline Sample & BET surface area $\left(\mathrm{m}^{2} / \mathrm{g}\right)$ \\
\hline $\mathrm{TiO}_{2}$ & 119.8 \\
$1 \mathrm{wt} \% \mathrm{Cu} / \mathrm{TiO}_{2}$ & 112.3 \\
5 wt. $\% \mathrm{Cu} / \mathrm{TiO}_{2}$ & 124.6 \\
$10 \mathrm{wt} \% \mathrm{Cu} / \mathrm{TiO}_{2}$ & 122.8 \\
15 wt. $\% \mathrm{Cu} / \mathrm{TiO}_{2}$ & 108.8 \\
$20 \mathrm{wt} . \% \mathrm{Cu} / \mathrm{TiO}_{2}$ & 82.7 \\
10 wt. $\% \mathrm{Cu} / \mathrm{Al}_{2} \mathrm{O}_{3}$ & 171.9 \\
\hline
\end{tabular}

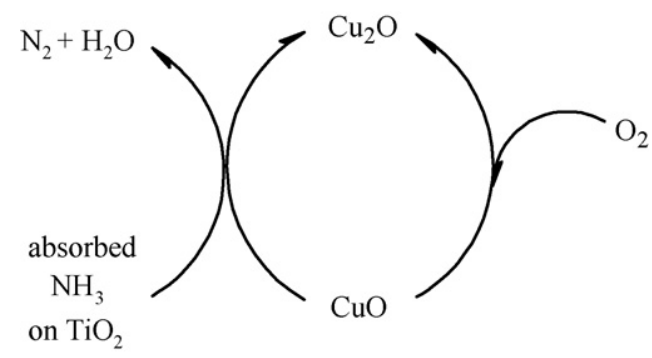

Fig. 7. Schematic mechanism of the $\mathrm{SCO}$ of $\mathrm{NH}_{3}$ on $\mathrm{Cu} / \mathrm{TiO}_{2}$.

main factor for the great difference of the activity between the two catalysts, and the synergetic effect between active $\mathrm{CuO}$ and the support might play an important role. We supposed that the $\mathrm{SCO}$ of ammonia on $\mathrm{Cu} / \mathrm{TiO}_{2}$ followed the oxidation-reduction mechanism shown in Fig. 7. Free ammonia was firstly adsorbed on the surface of $\mathrm{TiO}_{2}$, and then the adsorbed ammonia was oxidized through the redox cycle of $\mathrm{CuO}$ and $\mathrm{Cu}_{2} \mathrm{O}$ at certain temperature. Therefore, the catalytic activity of $\mathrm{Cu} / \mathrm{TiO}_{2}$ should be closely related to the $\mathrm{NH}_{3}$ adsorption on support and the redox ability of active component.

\subsection{TPR of ammonia}

The strength of oxygen bonding in $10 \% \mathrm{Cu} / \mathrm{TiO}_{2}$ and $10 \%$ $\mathrm{Cu} / \mathrm{Al}_{2} \mathrm{O}_{3}$ was determined by the TPR method. The TPR profiles of ammonia are shown in Fig. 8a and b, respectively. Forma-

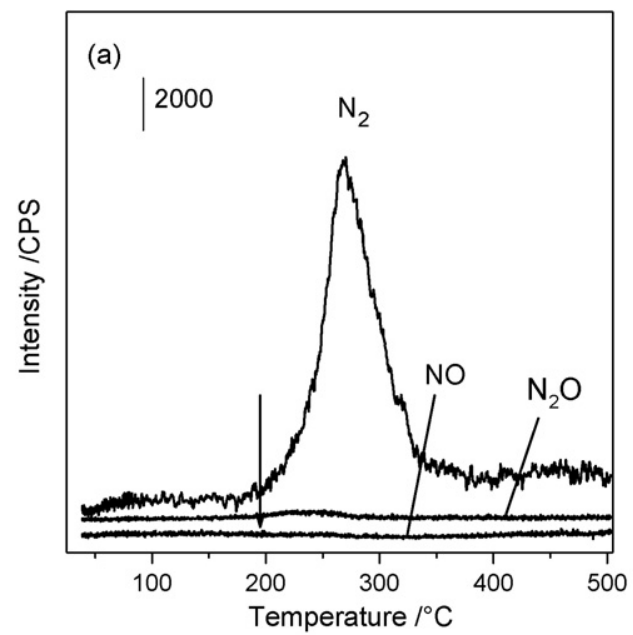

tion of $\mathrm{N}_{2}$ on the $10 \% \mathrm{Cu} / \mathrm{TiO}_{2}$ starts at temperature $200^{\circ} \mathrm{C}$ and reaches the maximum at about $250{ }^{\circ} \mathrm{C}$, while that on the $\mathrm{Cu} / \mathrm{Al}_{2} \mathrm{O}_{3}$ starts from $275^{\circ} \mathrm{C}$, and reaches the maximum at $370^{\circ} \mathrm{C}$. These results indicate that reduction of $\mathrm{CuO}$ on $\mathrm{TiO}_{2}$ is easier than that on $\mathrm{Al}_{2} \mathrm{O}_{3}$ by $\mathrm{NH}_{3}$. The oxygen mobility on $10 \% \mathrm{Cu} / \mathrm{TiO}_{2}$ is higher than that on $\mathrm{Cu} / \mathrm{Al}_{2} \mathrm{O}_{3}$, which is probably responsible for the much higher $\mathrm{SCO}$ activity of $\mathrm{Cu} / \mathrm{TiO}_{2}$ than that of $\mathrm{Cu} / \mathrm{Al}_{2} \mathrm{O}_{3}$ [16]. Apart from nitrogen production, trace amount of $\mathrm{N}_{2} \mathrm{O}$ was also produced on the $\mathrm{Cu} / \mathrm{TiO}_{2}$ during the $\mathrm{NH}_{3}$-TPR, but no $\mathrm{NO}_{x}$ was detected, even at higher temperature.

\subsection{TPD of adsorbed ammonia}

The surface acidity of the catalysts was measured by TPD of ammonia $\left(\mathrm{NH}_{3}\right.$-TPD), and the TPD profiles of ammonia on $10 \% \mathrm{Cu} / \mathrm{TiO}_{2}$ and $\mathrm{Cu} / \mathrm{Al}_{2} \mathrm{O}_{3}$ are shown in Fig. $9 . \mathrm{NH}_{3}$ desorption occurs from room temperatures up to $350^{\circ} \mathrm{C}$. Three peaks of ammonia desorption appeared, indicating that three major ammonia species differing in thermal stability exist on catalyst surface. The first two peaks should correspond to the physical desorption, and the last peak should be attributable to the chemical desorption. $\mathrm{N}_{2}$ and trace amount of $\mathrm{N}_{2} \mathrm{O}$ were also found around $270{ }^{\circ} \mathrm{C}$ from the reaction of chemisorbed $\mathrm{NH}_{3}$. However, no formation of $\mathrm{NO}$ was observed within the investigated temperatures. As shown in Fig. $9 \mathrm{~b}$, the $10 \% \mathrm{Cu} / \mathrm{Al}_{2} \mathrm{O}_{3}$ catalyst has a similar TPD profile of ammonia to $10 \% \mathrm{Cu} / \mathrm{TiO}_{2}$. The desorption peaks of ammonia, $\mathrm{N}_{2}$ and trace amount of $\mathrm{N}_{2} \mathrm{O}$ were observed, whereas NO desorption was not detected. The difference is that the chemical desorption occurred at different temperatures: $250{ }^{\circ} \mathrm{C}$ for $10 \% \mathrm{Cu} / \mathrm{TiO}_{2}$, and $350{ }^{\circ} \mathrm{C}$ for $10 \%$ $\mathrm{Cu} / \mathrm{Al}_{2} \mathrm{O}_{3}$, which is consistent with the experimental results of Gutieirrez-Alejandre's study that the temperature of ammonia chemical desorption decreased when the alumina support was mixed with titania [18]. It should be noted that no major change was observed when ammonia was co-adsorbed with oxygen.

\subsection{DRIFT results}

Fig. 10 shows the in situ DRIFT spectra of $10 \% \mathrm{Cu} / \mathrm{TiO}_{2}$ in a flow of $\mathrm{NH}_{3}+\mathrm{O}_{2}$ at various temperatures. The bands found

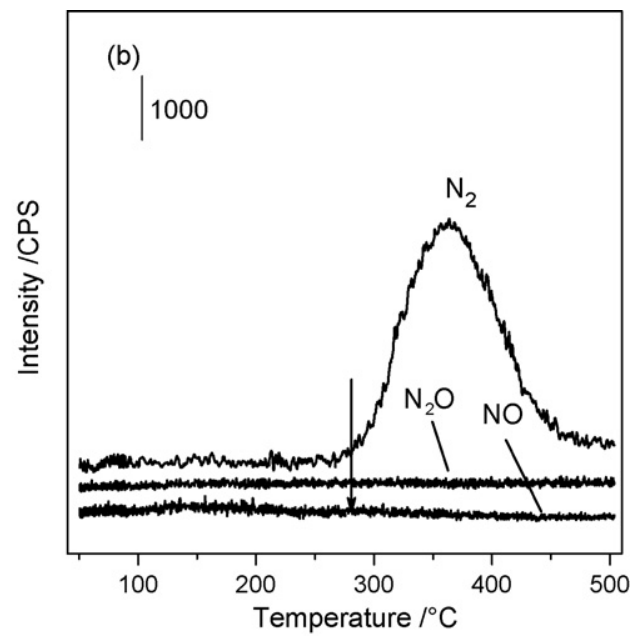

Fig. 8. Ammonia TPR profile on the catalysts of $10 \mathrm{wt} . \% \mathrm{Cu} / \mathrm{TiO}_{2}$ (a) and $10 \mathrm{wt} . \% \mathrm{Cu} / \mathrm{Al}_{2} \mathrm{O}_{3}$ (b). 

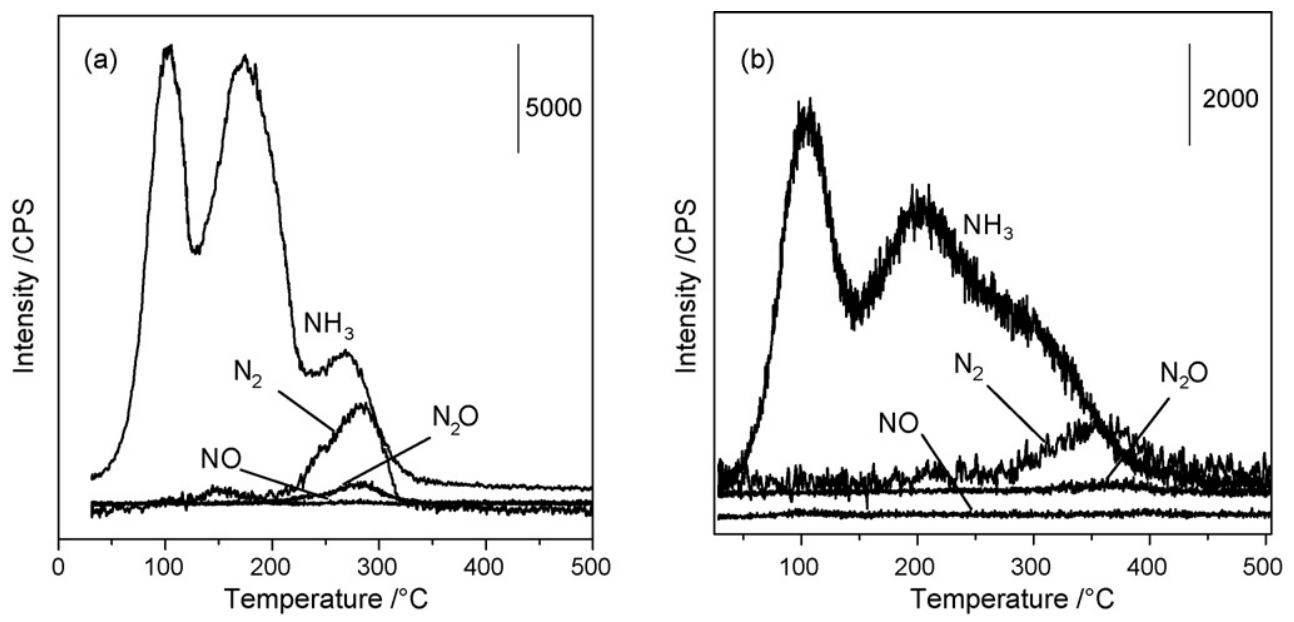

Fig. 9. Ammonia TPD profile on the catalysts of $10 \% \mathrm{Cu} / \mathrm{TiO}_{2}$ (a) and 10 wt. $\% \mathrm{Cu} / \mathrm{Al}_{2} \mathrm{O}_{3}$ (b).

at 1608 and $1223 \mathrm{~cm}^{-1}$ can be assigned to the asymmetric and symmetric deformation modes of ammonia, respectively, coordinated on Lewis acid sites. The bands at 3390, 3356, 3250 and $3149 \mathrm{~cm}^{-1}$ could be assigned to the $\mathrm{N}-\mathrm{H}$ stretching modes [19]. The bands at 1699 and $1460 \mathrm{~cm}^{-1}$ were due to the asymmetric and symmetric deformation modes of ammonia coordinated on Bronsted acid sites. The band at $1365 \mathrm{~cm}^{-1}$ can be assigned to $-\mathrm{NH}_{2}$ wagging deformation modes [20]. The intensities of these bands gradually decrease with the increasing of sample temperature. Compared with the TPD of $\mathrm{NH}_{3}$ (Fig. 9), the desorption of unreacted $\mathrm{NH}_{3}$ and the activation of $\mathrm{NH}_{3}$ are responsible for these decreases. In addition, it was worthy of note that no nitrate species appear over the temperature range investigated.

For the route of the SCO of ammonia to $\mathrm{N}_{2}$, two pathways have been proposed in the literature. The first is the in situ or "internal" selective catalytic reduction (iSCR). It is a two-step mechanism involving the oxidation of a significant percentage of the $\mathrm{NH}_{3}$ into $\mathrm{NO}_{x}$ species as follows [6]:

$$
\begin{aligned}
& \mathrm{NH}_{3}+\mathrm{O}_{2} \rightarrow \mathrm{NO}_{x}+\mathrm{H}_{2} \mathrm{O} \\
& \mathrm{NO}_{x}+\mathrm{NH}_{3}+\mathrm{O}_{2} \rightarrow \mathrm{N}_{2}+\mathrm{H}_{2} \mathrm{O}
\end{aligned}
$$

The second is a direct route based on the recombination of $2 \mathrm{NH}_{x}$ species giving rise to a hydrazinium intermediate $\mathrm{H}_{x} \mathrm{~N}-\mathrm{NH}_{x}[20,21]$, and the reactions are as follows:

$\mathrm{NH}_{3}(\mathrm{~g}) \rightarrow \mathrm{NH}_{3} \quad($ ads $)$

$\mathrm{NH}_{3} \quad($ ads $) \rightarrow \mathrm{NH}_{2} \quad($ ads $)+\mathrm{H}^{+}+\mathrm{e}$

$2 \mathrm{NH}_{2} \quad($ ads $) \rightarrow \mathrm{N}_{2} \mathrm{H}_{4} \quad$ (ads)
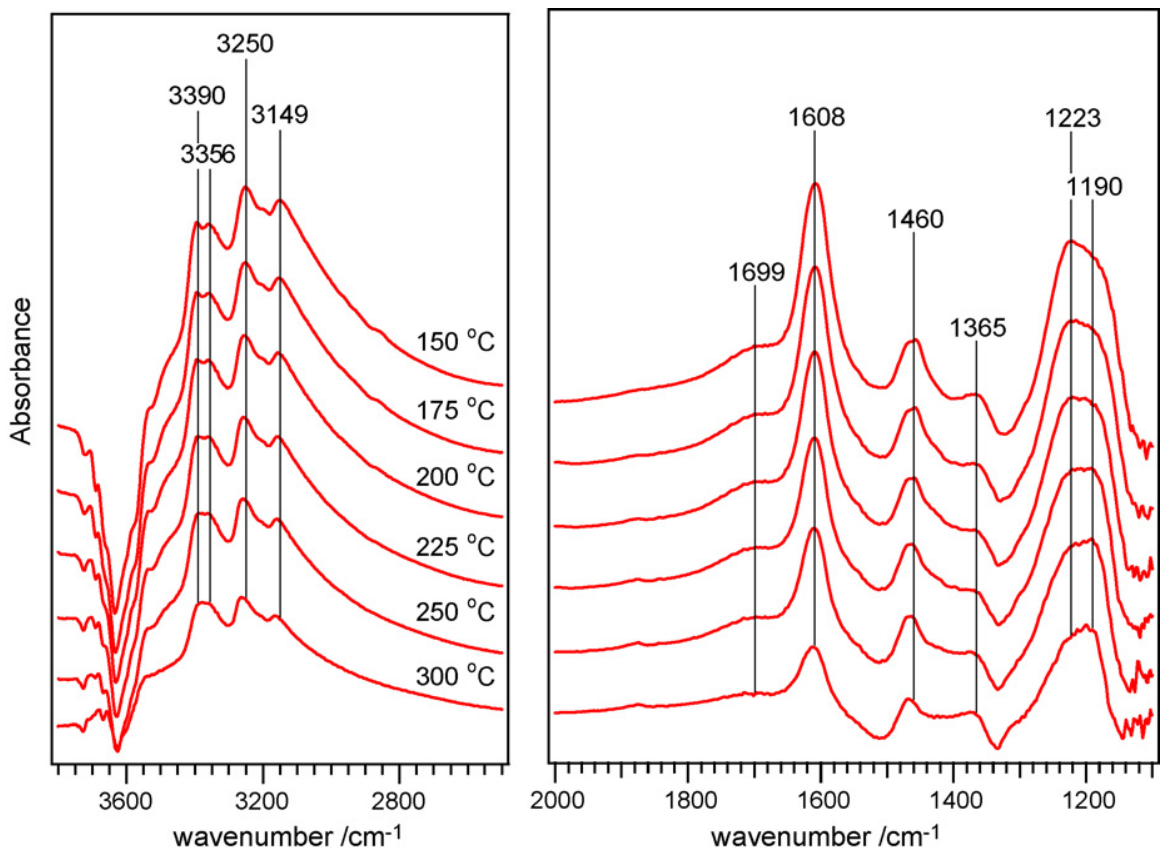

Fig. 10. In situ DRIFT spectra of $10 \% \mathrm{Cu} / \mathrm{TiO}_{2}$ catalyst in a flow of $\mathrm{NH}_{3}+\mathrm{O}_{2}$ at various temperatures. Reaction conditions: $0.2 \mathrm{~g}$ catalyst, [NH $3=400 \mathrm{ppm}$, $\left[\mathrm{O}_{2}\right]=10 \%, \mathrm{He}=$ balance, total flow rate $=500 \mathrm{ml} \mathrm{min}^{-1}$ and $\mathrm{GHSV}=50,000 \mathrm{~h}^{-1}$. 
$\mathrm{N}_{2} \mathrm{H}_{4} \quad($ ads $) \rightarrow \mathrm{N}_{2}+4 \mathrm{H}^{+}+4 \mathrm{e}$

According to our results of TPR, TPD and DRIFTS of $\mathrm{Cu} / \mathrm{TiO}_{2}$, the first hypothesis was apparently ruled out, because there did not appear $\mathrm{NO}_{x}$ species in the experimental process. Therefore, the direct path way was suitable for the SCO of ammonia to $\mathrm{N}_{2}$ on $\mathrm{Cu} / \mathrm{TiO}_{2}$ catalyst, i.e., the oxidation of $\mathrm{NH}_{x}$ species directly to atomic nitrogen and then the recombination of two nitrogen atoms forming $\mathrm{N}_{2}$, or the recombination of $\mathrm{NH}_{x}$ species giving rise to an hydrazinium intermediate $\mathrm{N}_{2} \mathrm{H}_{4}$ and then oxidizing to $\mathrm{N}_{2}$.

\section{Conclusions}

The $\mathrm{TiO}_{2}$ supported copper catalyst was found to be active for ammonia oxidation. The $\mathrm{Cu} / \mathrm{TiO}_{2}$ with $10 \% \mathrm{Cu}$ loading shows the best performance in its series in terms of $\mathrm{NH}_{3}$ conversion and $\mathrm{N}_{2}$ selectivity. Compared with $\mathrm{Al}_{2} \mathrm{O}_{3}, \mathrm{TiO}_{2}$ demonstrate a much higher activity for the SCO of ammonia as the supporting material because of the higher oxygen mobility in the system. The results of TPR, TPD and DRIFTS show that the SCO of $\mathrm{NH}_{3}$ follows the direct route, not the two-step mechanism.

\section{Acknowledgements}

This work was financially supported by the National Natural Science Foundation of China (50621804) and the Ministry of Science and Technology of China (2004AA649280, 2006AA060304).

\section{References}

[1] X.Z. Li, Q.L. Zhao, X.D. Hao, Ammonium removal from landfill leachate by chemical precipitation, Waste Manage. 19 (1999) 409-415.

[2] M. Altinbas, C. Yangin, I. Ozturk, Struvite precipitation from anaerobically treated municipal and landfill wastewaters, Water Sci. Technol. 46 (2002) 271-278.

[3] I. Stratful, M.D. Scrimshaw, J.N. Lester, Conditions influencing the precipitation of magnesium ammonium phosphate, Water Res. 35 (2001) 4191-4199.

[4] S. He, Y. Zhang, M. Yang, W. Du, H. Harada, Repeated use of MAP decomposition residues for the removal of high ammonium concentration from landfill leachate, Chemosphere 66 (2007) 2233-2238.
[5] M. Amblard, R. Burch, B.W.L. Southward, Study of the mechanism of selective conversion of ammonia to nitrogen on $\mathrm{Ni} / \gamma-\mathrm{Al}_{2} \mathrm{O}_{3}$ under strongly oxidizing conditions, Catal. Today 59 (2000) 365-371.

[6] M. de Boer, H.M. Huisman, R.J.M. Mos, R.G. Leliveld, A.J. Dillen, J.W. Geus, Selective oxidation of ammonia to nitrogen over $\mathrm{SiO}_{2}$-supported $\mathrm{MoO}_{3}$ catalysts, Catal. Today 17 (1993) 189-200.

[7] J.J. Ostermaier, J.R. Katzer, W.H. Manogue, Crystallite size effects in the low-temperature oxidation of ammonia over supported platinum, J. Catal. 33 (1974) 457-473.

[8] G. Lu, B.G. Anderson, J. van Grondelle, R.A. van Santen, Low temperature selective oxidation of ammonia to nitrogen on silver-based catalysts, Appl. Catal. B 40 (2003) 101-110.

[9] F.J.J.G. Janssen, F.M.G. Kerkhof, Selective catalytic removal of NO from stationary sources, KEMA Sci. Technol. Rep. 3 (1985).

[10] E.T.C. Vogt, A. Boot, J.W. Geus, F.J.J.G. Janssen, Preparation and performance of a silica-supported $\mathrm{V}_{2} \mathrm{O}_{5}$ on $\mathrm{TiO}_{2}$ catalyst for the selective reduction of $\mathrm{NO}$ with $\mathrm{NH}_{3}$, J. Catal. 114 (1988) 313-320.

[11] G. Tuenter, W.F. van Leeuwen, L.J.M. Snepvangers, Kinetics and mechanism of the $\mathrm{NO}_{x}$ reduction with $\mathrm{NH}_{3}$ on $\mathrm{V}_{2} \mathrm{O}_{5}-\mathrm{WO}_{3}-\mathrm{TiO}_{2}$ catalyst, Ind. Eng. Chem. Prod. Res. Dev. 25 (1986) 633-636.

[12] J.J.P. Biermann, F.J.J.G. Janssen, J.W. Geus, Molybdena on silica catalysts: selective catalytic oxidation of ammonia to nitrogen over $\mathrm{MoO}_{3}$ on $\mathrm{SiO}_{2}$ catalysts, J. Mol. Catal. 60 (1990) 229-238.

[13] M. Yang, C. Wu, C. Zhang, H. He, Selective oxidation of ammonia over copper-silver-based catalysts, Catal. Today 90 (2004) 263-267.

[14] N.N. Sazonova, A.V. Simakov, T.A. Nikoro, G.B. Barannik, V.F. Lyakhova, V.I. Zheivot, Z.R. Ismagilov, H. Veringa, Selective catalytic oxidation of ammonia to nitrogen, React. Kinet. Catal. Lett. 57 (1996) 71-79.

[15] J. Lu Gang, B.G. van Grondelle, R.A. Anderson, van Santen, Selective low temperature $\mathrm{NH}_{3}$ oxidation to $\mathrm{N}_{2}$ on copper-based catalysts, J. Catal. 186 (1999) 100-109.

[16] L. Chmielarz, P. Kustrowski, A. Rafalska-Lasocha, R. Dziembaj, Selective oxidation of ammonia to nitrogen on transition metal containing mixed metal oxides, Appl. Catal. B 58 (2005) 235-244.

[17] Y. Li, J.N. Armor, Selective $\mathrm{NH}_{3}$ oxidation to $\mathrm{N}_{2}$ in a wet stream, Appl. Catal. B 13 (1997) 131-139.

[18] A. Gutiěrrez-Alejandre, M. Gonzǎlez-Cruz, M. Trombetta, G. Busca, J. Ramırreza, Characterization of alumina-titania mixed oxide supports: Part II: $\mathrm{Al}_{2} \mathrm{O}_{3}$-based supports, Microporous Mesoporous Mater. 23 (1998) 265-275.

[19] G. Ramis, L. Yi, G. Busca, M. Turco, E. Kotur, R.J. Willey, Adsorption, activation, and oxidation of ammonia over SCR catalysts, J. Catal. 157 (1995) 523-535.

[20] G. Ramis, L. Yi, G. Busca, Ammonia activation over catalysts for the selective catalytic reduction of $\mathrm{NO}_{x}$ and the selective catalytic oxidation of $\mathrm{NH}_{3}$ : an FT-IR study, Catal. Today 28 (1996) 373-380.

[21] J.M.G. Amores, V.S. Escribano, G. Ramis, G. Busca, An FT-IR study of ammonia adsorption and oxidation over anatase-supported metal oxides, Appl. Catal. B 13 (1997) 45-58. 